\title{
Variasi Leksikal Bahasa Musi di Sungsang
}

\author{
Andina Muchti $\&$ Delvi Selvia² \\ Universitas Bina Darma1; SMP Negeri 1 Banyuasin² \\ Corresponding email: andina.muchti@binadarma.ac.id
}

\begin{abstract}
This study aims to describe the lexical variations of the Musi language in Sungsang. This lexical variation can be demonstrated by looking for similarities and differences in Musi language variations in Sungsang. The method used is a qualitative description. Data collection techniques using observation, interviews, recording, and recording techniques. Data analysis techniques data checking with data reduction, data transcription, data classification, data interpretation, and conclusions. The results showed that: 1) Swades basic vocabulary there are 20 different words and 20 similarity words, 2) body parts there are 5 differences and 6 similarities, 3) greeting pronouns there are 4 different words and 2 similarity words 4) kinship system there are 3 words differences and 2 words of equality, 5) village and community life there are 7 words of difference and 4 words of equality, 6) house and parts there are 7 words of difference and 5 words of equality, 7) equipment and supplies there are 10 words of difference and 6 words of similarity, 8) food and drinks there are 5 words of difference and 2 words of equality, 9) seasons, natural conditions, natural objects, and directions there are 14 words of difference and 9 words of equality, 10) mannerism and adjectives there are 20 words of difference and 5 words of similarity, 11) clothing and jewelry there are 6 words of difference and 8 words of equality, 12) motion and work there are 20 words of difference and 10 words of equality, and 12) animals there are 6 words of difference and 1 similarity of language Musi, ko sakata that do not experience differences in plant, yard and tree vocabulary. Musi language variations are mostly found in Sungsang I Village with 60 vocabularies, while Musi language equation is more in Sungsang III village with 162 vocabularies.
\end{abstract}

Keywords: lexical variation, Musi Sungsang language

\begin{abstract}
Abstrak
Penelitian ini bertujuan untuk mendeskripsikan variasi leksikal bahasa Musi di Sungsang. Variasi leksikal ini bisa ditunjukkan dengan mencari persamaan dan perbedaan variasi bahasa Musi di Sungsang. Metode yang digunakan adalah deskripsi kualitatif. Teknik pengumpulan data menggunakan teknik observasi, wawancara, pencatatan, dan rekaman. Teknik analisis data pengecekan data dengan reduksi data, transkripsi data, klasifikasi data, interpretasi data, dan kesimpulan. Hasil penelitian menunjukkan bahwa: 1) kosakata dasar Swades terdapat 20 kata perbedaan dan 20 kata persamaan, 2) bagian tubuh terdapat 5 perbedaan dan 6 persamaan, 3) kata ganti sapaan terdapat 4 kata perbedaan
\end{abstract}


dan 2 kata persamaan 4) sistem kekerabatan terdapat 3 kata perbedaan dan 2 kata persamaan, 5) kehidupan desa dan masyarakat terdapat 7 kata perbedaan dan 4 kata persamaan, 6) rumah dan bagian-bagianya terdapat 7 kata perbedaan dan 5 kata persamaan, 7) peralatan dan perlengkapan terdapat 10 kata perbedaan dan 6 kata persamaan, 8) makanan dan minuman terdapat 5 kata perbedaan dan 2 kata persamaan, 9) musim, keadaan alam, benda alam, dan arah terdapat 14 kata perbedaan dan 9 kata persamaan, 10) perangai dan kata sifat terdapat 20 kata perbedaan dan 5 kata persamaan, 11) pakaian dan perhiasan terdapat 6 kata perbedaan dan 8 kata persamaan, 12) gerak dan kerja terdapat 20 kata perbedaan dan 10 kata persamaan, dan 12) binatang terdapat 6 kata perbedaan dan 1 persamaan bahasa Musi, kosakata yang tidak mengalami perbedaan pada kosakata tanaman, halaman, dan pepohonan. Variasi Bahasa Musi banyak terdapat di Desa Sungsang I dengan jumlah 60 kosakata, sedangkan persamaan bahasa Musi lebih banyak di desa Sungsang III dengan jumlah 162 kosakata.

Kata kunci: variasi leksikal, bahasa Musi Sungsang

\section{PENDAHULUAN}

Bahasa merupakan alat untuk berinteraksi atau alat untuk menyampaikan pikiran, gagasan, konsep, dan perasaan dalam suatu kelompok sosial tertentu (Felicia, 2001). Selain itu, di era globalisasi ini bahasa sangat berperan penting karena berfungsi sebagai alat dalam berkolaborasi, bekerja sama, melakukan kreativitas, dan berpikir kritis dalam menyampaikan pendapat (Noermanzah \& Friantary, 2019:6631). Untuk itu, pentingnya kita mempelajari bahasa dan mengkaji bahasa agar bahasa tersebut tetap berkembang dan tetap menjadi alat komunikasi. Salah satu bahasa daerah yang masih digunakan oleh masyarakat Kabupaten Musi Banyuasin di Provinsi Sumatera Selatan adalah bahasa Musi yang masih berkerabat dengan bahasa Sindang di Kabupaten Musi Rawas dan sekitarnya. Bahasa Musi sampai sekarang masih menjadi alat komunikasi utama dalam kehidupan sehari-hari, juga digunakan dalam berbagai aktivitas, misalnya dalam upacara perkawinan, upacara adat, dan proses jual beli di pasar tradisional (Noermanzah, 2017:2).

Bahasa Musi di daerah Sungsang berfungsi sebagai alat perhubungan yang efektif terutama di lingkungan keluarga, di lingkungan masyarakat dan di dalam pertemuan yang tidak resmi. Sebagian besar mata pencarian daerah Sungsang adalah nelayan tangkap karena merupakan daerah perairan. Bahasa Musi ini juga masih digunakan oleh masyarakat di Sungsang dalam kehidupan sehari-hari sebagai alat komunikasi. Sungsang memiliki luas 193,021.5 km, dengan jumlah penduduk sebanyak 19.290 jiwa. Berdasarkan latar belakang di atas, penulus merumuskan masalah dalam penelitian ini yaitu, Bagaimanakah variasi perbedaan dan persamaan bahasa Musi di Sungsang dari segi leksikal?

Sehubungan dengan bahasa sebagai alat komunikasi bagi manusia sehingga manusia memerlukan bahasa untuk berhubungan dan bekerja sama. Menurut Chaer \& Agustina (2010:11) bahwa bahasa adalah sebuah sistem lambang, berupa bunyi, bersifat artiber, produktif, dinamis, beragam dan manusiawi. Bahasa dapat berhubungan dengan orang lain. Hubungan dengan orang lain bisa berupa menanyakan, menyatakan, mengharapkan, menyuruh, meminta, dan sebagainya (Pateda, 1988:12). 
Sosiolinguistik merupakan kajian tentang bahasa yang dikaitkan dengan kondisi kemasyarakatan yang ada. Menurut Chaer \& Agustina (2010:2), Sosiolinguistik adalah bidang ilmu antardisiplin yang mempelajari bahasa dalam kaitanya dengan penggunaan bahasa di dalam masyarakat. J.A. Fishman dalam Chaer \& Agustina (2010:3), menjelaskan Sosiolinguistik merupakan kajian tentang variasi bahasa atau ciri khas dalam suatu bahasa, fungsi-fungsi variasi bahasa dan pemakaian dalam bahasa ketiga tersebut saling berinteraksi, berubah, dan saling mengubah satu sama lain dalam satu masyarakat tutur. Variasi atau ragam bahasa dapat kita lihat berdasarkan adanya keragaman serta fungsi kegiatan di dalam masyarakat sosial. Menurut Aslinda (2010:16), pemakaian bahasa tidak hanya dipengaruhi oleh faktor linguistik, tetapi juga dipengaruhi faktor nonlinguistik. Faktor nonlinguistik yakni, faktor sosial yang dapat mempengaruhi pemakaian bahasa yang terdiri dari status sosial, tingkatan pendidikan, umur, jenis kelamin, dan sebagainya. Selain itu juga bisa disebabkan oleh pensentuhan bahasa satu dengan bahasa lain karena para penutur yang bilingual (Chaer dalam Mutoharoh dkk., 2018:87).

Bahasa Musi (BM) berdasarkan uraian Aliana (2003:71) bahwa nama bahasa Musi diambil dari nama sungai yang mengalir melalui daerah Musi Banyuasin, yaitu Sungai Musi. Menurut Gani dkk. (dikutip oleh Aliana, 2003:71) terdapat sebanyak 361.798 orang yang bertempat tinggal di daerah Kabupaten Musi Banyuasin dan sekitar 36.179 orang yang tinggal di daerah Kabupaten Musi Banyuasin. Wilayah pemakaian bahasa Musi mencakupi dua daerah kabupaten, yaitu Kabupaten Musi Banyuasin (MUBA) dan Kabupaten Musi Rawas (MURA). Khusus, di Kabupaten MUBA, bahasa Musi digunakan di beberapa kecamatan yaitu; (1) Sekayu, (2) Babat Toman, (3) Banyuasin I, (4) Banyuasin II, (5) Banyuasin III, (6) Talang Kelapa, (7) Sungai Lilin, dan (8) Banyug Linci. Sedangkan di Kabupaen MURA, Bahasa Musi digunakan di tiga Kecamatan, yaitu (1) Muara Kelingi, (2) Bingin Teluk, dan (3) Muara Beliti. Dalam Bahasa Musi tidak terdapat dialek regional, yang ada hanyalah variasi bahasa dalam bidang kosakata.

Penelitian tentang variasi leksikal bahasa Musi sudah pernah diteliti oleh Dedi \& Cekman (2018:67), tetapi penelitiannya hanya sebatas pada kohesi leksikal bahasa Musi yang masih berkerabat dengan bahasa Sindang Kelingi pada upacara Berasan masyarakat Sindang Kelingi Kabupaten Musi Rawas. Hal ini menunjukkan bahwa variasi leksikal bahasa Musi di Sungkang Kabupaten Musi Banyuasin belum diteliti.

\section{METODE}

Metode yang digunakan dalam penelitian ini adalah metode deskriptif kualitatif. Dengan menggunakan metode deskriptif kualitatif, sumber data yang digunakan dalam penelitian ini adalah penutur asli bahasa Musi di Sungsang, bahasa pertamanya adalah bahasa Musi di Sungsang yang diperoleh sewaktu belajar atau berbicara yang diperoleh pada masa anak-anak sampai dengan sekarang. Djadjasudarma (1993:20) mengatakan bahwa informan dapat ditentukan dari segi jumlah terbatas, karena informan bahasa merupakan mekrokosmos dari masyarakat bahasanya (satu orang dapat mewakili masyarakat bahasanya).

Pemilihan informan dalam penelitian ini dengan memperhatikan syarat-syarat menurut Mahsun (2006:134) sebagai berikut: 
1. berjenis kelamin pria atau perempuan;

2. berusia antara 25-65 tahun (tidak pikun);

3. Orang tua, istri, atau suami informan lahir dibesarkan di desa itu serta jarang atau tidak pernah meninggalkan desanya;

4. berpendidikan maksimal tamat pendidikan dasar (SD-SLTP);

5. berstatus sosial menengah (tidak rendah atau tidak tinggi) dengan harapan tidak terlalu tinggi mobilitasnya;

6. pekerjaannya bertani atau buruh;

7. memiliki kebanggaan terhadap isoleknya;

8. dapat berbahasa indonesia; dan

9. sehat jasmani dan rohani, (maksudnya tidak cacat dalam berbahasa dan memiliki pendengaran yang tajam untuk dapat menangkap pertanyaanpertanyaan dengan tepat sedangkan sehat rohani tidak gila atau pikun).

Berkaitan dengan kosakata dasar Swadesh, merupakan daftar pertanyaan yang akan membantu untuk mengarahkan pencapaian informasi dan memfokuskan informan pada satu topik pembicaraan ketika pertanyaanpertanyaan itu diajukan. Penelitian ini menggunakan 200 daftar kosakata dasar swadesh yang telah dikembangkan oleh Mahsun (2006:297), yaitu kosakata yang berhubungan dengan: kosakata dasar Swadhes; bagian tubuh; kata ganti sapaan; sistem kekerabatan; kehidupan desa dan masyarakat; rumah dan bagianbagiannya; peralatan dan perlengkapan; makanan dan minuman; tanaman, halaman, dan pepohonan; musim, keadaan alam, benda alam, dan arah; perangai dan kata sifat; pakaian dan perhiasan; gerak dan kerja; serta binatang.

Penelitian ini dilakukan di Sungsang yang menempatkan 4 Desa di Sungsang yaitu Desa Sungsang I, Sungsang II, Desa Sungsang III, dan Desa Sungsang IV. Waktu penelitian selama 2 minggu, 1 minggu peneliti melakukan observasi, guna mencari sendiri informan yang sesuai dengan kriteria yang telah ditentukan, kemudian peneliti menentukan waktu untuk melakukan wawancara dengan informan. Satu minggu berikutnya, peneliti melakukan tanya jawab dengan informan.

Pengumpulan data dilakukan untuk mengumpulkan data yang berhubungan dengan penelitian variasi leksikal bahasa Musi di Sungsang. Adapun teknik pengumpulan data yang digunakan sebagai berikut:

1. Observasi

Dalam proses observasi ini, peneliti secara langsung datang ke Sungsang untuk mengamati daerah tersebut serta bahasa yang digunakan di masyarakat Sungsang. Dengan ini maka data yang diperoleh akan lebih lengkap.

\section{Wawancara}

Wawancara dilakukan untuk mengetahui seluk-beluk daerah yang akan diteliti dan mengetahui tentang variasi bahasa di daerah Sungsang. Dalam melakukan wawancara peneliti telah menyiapkan daftar pertanyaan tertulis yang akan dibacakan oleh peneliti kepada informan sehingga informan hanya mendengarkan dan menjawab pertanyaan yang dibacakan peneliti. Panduan wawancara yang digunakan dalam penelitian ini difokuskan untuk empat orang informan dengan pertanyaan yang sama untuk ke empat informan tersebut.

3. Teknik Pencatatan

Daftar pertanyaan yang diberikan kepada informan sesuai dengan daftar pertanyaan wawancara. Setiap jawaban yang dipeloreh akan langsung dicatat dengan transkrip fonetis. 


\section{Teknik Rekaman}

Teknik rekaman bersifat melengkapi data yang diperoleh dengan teknik catat. Teknik ini digunakan agar data yang sudah dicatat bisa dilihat kembali dengan rekaman yang dihasilkan.

Metode yang digunakan untuk menganalisis data adalah metode padan. Teknik analisis data yang digunakan dalam metode padan adalah teknik dasar dan teknik lanjutan. Menurut Sudaryanto (2015:25) teknik dasar adalah teknik pilah sebagai penentu (alat ucap). Teknik ini digunakan untuk melihat persamaan dan perbedaan secara leksikal.

Sudaryanto (2015:15), mengemukakan teknik lanjut adalah teknik yang membandingkan atau mencari semua kesamaan dan perbedaan yang ada di antara kedua yang dibandingkan sehingga dapat dikatakan menjadi hubungan penyamaan dan hubungan perbedaan. Dalam teknik lanjutan ada dua teknik yang digunakan yaitu: teknik hubung banding menyamakan yang mencari persamaan bahasa di empat desa yaitu bahasa Musi dari Desa Sungsang 1, Desa Sungsang II, Desa Sungsang III dan Desa Sungsang IV, dan teknik hubung banding membedakan dengan cara mencari perbedaan bahasa Musi di Sungsang dari empat desa, yaitu Desa Sungsang I, Desa Sungsang II, Desa Sungsang III, dan Desa Sungsang IV. Langkah-langkah yang dilakukan dalam menganalisis data sebagai berikut.

1. mengecek kembali kelengkapan data yang sudah di siapkan;

2. memeriksa isi instrumen pengumpulan data agar tidak ada masalah ketika dalam proses penelitian berlangsung;

3. hasil data yang diperoleh berdasarkan wawancara berisi kosakata Swadesh akan ditranskripsikan ke dalam fonologi;

4. setelah data telah ditranskripsikan lalu diklasifikasikan berdasarkan hubung banding menyamakan (HBS) dan hubung banding membedakan (HBSP);

5. data yang sudah diklasifikasikan akan dianalisis dan dimuat berdasarkan tabel maupun bagan; dan

6. setelah data dianalisis dan disimpulkan, kemudian ditarik kesimpulan.

\section{HASIL}

Penelitian ini membahas perbedaan dan persamaan bahasa Musi di Sungsang. Perbedaan dan persamaan ini terjadi akibat letak geografis, karena Sungsang merupakan pintu lalu lintas sehingga menyebabkan keberagaman bahasa. Hasil penelitian ini akan dijelaskan data dari hasil analisis data berupa kosakata dalam bahasa Musi di Sungsang yang dibandingkan dengan menggunakan kosakata Swadesh.

Kosakata merupakan bagian yang penting dalam penelitian ini. Kosakata yang digunakan sebanyak 200 kata. Kosakata tersebut diambil dari kosakata Swadesh yang sudah dikembangkan oleh Mahsun (2006:297). Kosakata yang digunakan terdiri dari 14 bidang yaitu, 1) kosa kata dasar swadesh, 2) bagian tubuh, 3) kata ganti sapaan, 4) sistem kekerabatan, 5) kehidupan desa dan masyarakat, 6) rumah dan bagian-bagianya, 7) peralatan dan perlengkapan, 8) makanan dan minuman, 9) tanaman, halaman, dan pepohonan, 10) musim, keadaan alam, benda, dan arah, 11) perangai dan kata sifat, 12) pakaian dan perhiasan, 13) gerak dan perhiasan, dan 14) bintang. 
Penyebab terjadinya perbedaan leksikal bahasa Musi di Sugsang terjadi karena Sungsang merupakan pintu gerbang lalu lintas, yang akan disingahi oleh masyarakat luar Sungsang, sehingga terjadinya komunikasi dengan desa luar dan desa di Sungsang itu sendiri. Perlahan-lahan kosakata yang digunakan mengalami perubahan. Perubahan itulah yang menyebabkan perbedaan kosakata di desa Sungsang dengan arti kata yang sama.

1) Perbedaan Bahasa Musi di Sungsang

Sebagai contoh, untuk bahasa Musi di Sungsang terdapat 4 kata yang digunakan untuk merealisasikan makna 'gemuk' 'gəndつt', 'bวntEt', 'gəmวk', 'gədi'. Sedangkan untuk merealisasikan makna 'jatuh', terdapat 3 kata, yaitu 'jəlepak', 'campak', dan 'ǹampak dan 2 kata untuk merealisasikan makna 'baring', yaitu nolen' dan 'təlentan'.

Pada kategori kosakata dasar, terdapat 20 kata yang memiliki perbedaan bahasa Musi di Sungsang. Dari hasil penelitian yang telah dilakukan, salah satu contoh ada pada kosakata dasar sebagai berikut: kata 'ayah' memunculkan dua variasi di empat desa tersebut yaitu: kata 'aba' digunakan di Desa Sungsang I, II dan kata 'Ebak' digunakan di Desa Sungsang III dan IV.

\section{Persamaan Bahasa Musi di Sungsang}

Persamaan bahasa Musi di Sungsang terjadi di empat desa di Sungsang persamaan ini terjadi karena masyarakat tetap menjaga/menggunakan kosakata bahasa itu sendiri sehingga tidak terjadinya perubahan kosakata, Bahasa tersebut masih digunakan sampai sekarang. Beberapa contoh persamaan bahasa Musi di Sungsang. Kata 'dengan' dengan transkripsi fonetik'dEngEn', kata 'tajam' dengan transkripsi fonetik 'landEp', kata 'hamil' dengan transkripsi fonetik 'bכnten' digunakan di desa.

Pada kategori kosakata dasar, terdapat 20 kata persamaan bahasa Musi di Sungsang dari hasil penelitian yang telah dilakukan salah satu contoh ada pada kosakata dasar sebagai berikut: kata 'air' dengan transkripsi fonetik (aEr) memiliki persamaan bahasa Musi di Desa Sungsang I, II, III, dan IV.

\section{PEMBAHASAN}

Berdasarkan penelitian yang telah dilakukan di Desa Sungsang. Sungsang memiliki perbedaan dan persamaan dari segi leksikal, adapun desa yang menjadi titik pengamatan terdiri dari 4 desa yaitu, Desa Sungsang I, Desa Sungsang II, Desa Sungsang III, dan Desa Sungsang IV. Perbedaan dan persamaan ini terjadi akibat letak geografis, karena daerah Sungsang merupakan pintu lalu lintas sehingga menyebabkan keragaman bahasa. Hal ini sesuai dengan pendapat Aslinda (2010:16), perbedaan dan persamaan penggunaan bahasa di suatu daerah tidak hanya dipengaruhi oleh faktor linguistik, tetapi juga dipengaruhi faktor nonlinguistik. Faktor nonlinguistik yakni, faktor sosial yang dapat mempengaruhi pemakaian bahasa yang terdiri dari status sosial, tingkatan pendidikan, umur, jenis kelamin dan sebagainya. Akan tetapi, yang menarik dalam penelitian ini persamaan dan perbedaan variasi leksikal sangat dominan diakibatkan oleh faktor letak geografis, karena daerah Sungsang merupakan pintu lalu lintas sehingga menyebabkan keragaman bahasa. Untuk mengetahui lebih lanjut mengenai variasi leksikal bahasa Musi di Sungsang dapat kita lihat sebagai berikut. 


\section{a. Variasi Leksikal}

Variasi leksikal yang dijelaskan pada penelitian ini dilihat dari perbedaan dan persamaan bahasa Musi yang digunakan oleh masing-masing desa di Sungsang. Variasi leksikal ini dibedakan dengan 14 kategori, yaitu kosakata dasar Swadesh, bagian tubuh, kata kanti sapaan, sistem kekerabatan, peralatan dan perlngkapan, makanan dan minuman, tanaman, halaman, dan pepohonan, musim, keadaan alam, benda alam dan arah, perangai dan kata sifat, pakaian dan perhiasaan, gerak dan kerja, dan binatang. Untuk lebih jelas dapat dilihat dari tabel di bawah ini.

\section{Tabel 1. Perbedaan dan Persamaan Variasi Leksikal Bahasa Musi di Sungsang} Berdasarkan Kosakata Dasar Swadesh

\begin{tabular}{|c|c|c|c|c|c|c|}
\hline \multirow[t]{2}{*}{ No. } & \multirow[t]{2}{*}{ Kata } & \multicolumn{4}{|c|}{ Desa Sungsang } & \multirow[t]{2}{*}{ Keterangan } \\
\hline & & I & II & III & IV & \\
\hline 1. & Air & $A \varepsilon r$ & $\mathrm{a} \varepsilon \mathrm{r}$ & $\mathrm{a} \varepsilon \mathrm{r}$ & $a \varepsilon r$ & Persamaan \\
\hline 2. & Ayah & Aba & Aba & Ebak & Ebak & Perbedaan \\
\hline 3. & Bagaimana & Maqmane & Maqmane & Caqmane & Caqmane & Perbedaan \\
\hline 4. & Baring & nolen & nolen & təlentan & nolen & Perbedaan \\
\hline 5. & Balik & Bale & Bale & Bale & Bale & Persamaan \\
\hline 6. & Besar & gədi & gədi & gədi & gədi & Persamaan \\
\hline 7. & Buah & BUah & bUah & bUah & bUah & Persamaan \\
\hline 8. & Bunuh & bכnכh & bכnכh & bכnכh & bכnכh & Persamaan \\
\hline 9. & Buruk & tak bagos & tak bagos & bərok & bכrok & Perbedaan \\
\hline 10. & Cium & ǹiวm & ǹiวm & clom & clom & Perbedaan \\
\hline 11. & Dengan & $D \varepsilon \eta \varepsilon n$ & $\mathrm{~d} \varepsilon \eta \varepsilon n$ & $d \varepsilon \eta \varepsilon n$ & $\mathrm{~d} \varepsilon \eta \varepsilon n$ & Persamaan \\
\hline 12. & Duduk & dつdכk & dつdכk & dつdכk & cวgJh & Perbedaan \\
\hline 13. & Di dalam & Di dalEm & Masok & Di dalEm & Masok & Perbedaan \\
\hline 14. & Ember & $E m b \varepsilon r$ & Pan & Pan & Taban & Perbedaan \\
\hline 15. & Engkau & Kau & Kau & $\mathrm{Kau}$ & $\mathrm{Kau}$ & Persamaan \\
\hline 16. & Gemuk & gəndวt & bכntEt & gəmวk & gədi & Perbedaan \\
\hline 17. & Hantam & Lanjakela & slkat & lajUkela & Hajar & Perbedaan \\
\hline 18. & Hitam & Iren & Iren & Iren & hltEm & Perbedaan \\
\hline 19. & Ibu & Emak & Emak & Emak & $\varepsilon$ bo & Perbedaan \\
\hline 20. & Istri & blnl & blnl & blnl & blnl & Persamaan \\
\hline 21. & Jatuh & jəlepak & Campak & ǹampak & Campak & Persamaan \\
\hline 22. & Kami, kita & Tobo & Tobo & Kame & Kame & Perbedaan \\
\hline 23. & Kaki & sUkU & sUkU & sUkU & sUkU & Persamaan \\
\hline 24. & Kamu & $\mathrm{Kau}$ & $\mathrm{Kau}$ & $\mathrm{Kau}$ & $\mathrm{Kau}$ & Persamaan \\
\hline 25. & Kakek & $\mathrm{y} \varepsilon \mathrm{k}$ & gəde & lyEk & gEdEh & Perbedaan \\
\hline 26. & Kening & Batวk & Batวk & Batวk & Batวk & Persamaan \\
\hline 27. & Kering & kəren & kəren & kəren & kəren & Persamaan \\
\hline 28. & Kutu & TUmU & tUmU & tUme & tUme & Persamaan \\
\hline 29. & Lihat & ǹele & jinjk & jlnכk & ǹin0 & Perbedaan \\
\hline 30. & Lelaki & Lanan & Lanan & Lanan & Lanan & Persamaan \\
\hline 31. & Leher & Gorokkan & Gorokkan & Gorokkan & Gorokkan & Persamaan \\
\hline 32. & Nenek & ǹebo & bวyวt & ǹEk & ǹai & Perbedaan \\
\hline 33. & Orang & Uran & Uran & Uran & Uran & Persamaan \\
\hline 34. & Perempuan & wadวn & wadวn & wadวn & bətlne & Perbedaan \\
\hline 35. & Sungai & sUni & sUnji & sune & sUne & Perbedaan \\
\hline 36. & Tajam & LandEp & landEp & landEp & landEp & Persamaan \\
\hline 37. & Tarik & TarEk & tarEk & tarEk & tarEk & Persamaan \\
\hline 38. & Kabut & kabət & kabot & kabst & kabot & Persamaan \\
\hline 39. & Tidur & tədつk & tədつk & tədつk & tədつk & Persamaan \\
\hline 40. & Tua & TUe & tUe & tUe & tUe & Persamaan \\
\hline
\end{tabular}




\section{b. Perbedaan Bahasa Musi di Sungsang}

Berdasarkan pada tabel 1 di atas, diperoleh perbedaan leksikal pada nomor $(2,3,4,9,10,12,13,14,16,17,18,19,21,22,25,29,32,34,35)$ mengalami perbedaan kosakata, seperti kata 'ayah', 'bagaimana', 'baring', 'cium', 'duduk', 'di dalam', 'ember', 'gemuk', 'hantam', 'hitam', 'ibu', 'jatuh', 'kami', 'kita', 'kakek', 'kutu lihat', 'nenek', 'perempuan', 'sungai', dan 'buruk'.

Pada kata 'aba' terdapat dua variasi leksikal. Varian pertama, yaitu 'aba' yang digunakan di Desa Sungsang I, Desa Sungsang II, kata 'Ebak' yang digunakan di Desa Sungsang III, dan Desa Sungsang IV. Kata 'bagaimana' terdapat dua variasi leksikal. Varian pertama, yaitu 'maqmane' yang digunakan di Desa Sungsang I, Desa Sungsang II, varian kedua, 'caqmane' digunakan di Desa Sungsang III dan Desa Sungsang IV. Kata 'baring' terdapat dua variasi leksikal. Varian pertama, yaitu 'nJlen' digunakan di Desa Sungsang I, Desa Sungsang II, Desa Sungsang IV, varian kedua, 'təlentan' digunakan di Desa Sungsang III.

Kata 'cium' memunculkan dua variasi leksikal. Di desa Sungsang I, Desa Sungsang II menggunakan kata ' ǹism' sedangkan Desa Sungsang III, Desa Sungsang IV menggunaka kata 'clım'. Kata 'duduk' memunculkan dua variasi leksikal. Di Desa Sungsang I, Desa Sungsang II, Desa Sungsang III, kata 'dつdつk' Desa Sungsang IV menggunakan kata 'cכgวh'. Kata 'di dalam' terdapat dua variasi leksikal. Varian pertama, yaitu 'Di dalEm' yang digunakan di Desa Sungsang I, Desa Sungsang III, sedangkan kata 'masวk' digunakan di Desa Sungsang II, dan Desa Sungsang IV. Kata 'ember' memunculkan tiga variasi leksikal. Di Desa Sungsang I mengatakan 'embEr' Desa Sungsang II, Desa Sungsang III menggunakan kata 'Pan' Desa Sungsang IV menggunakan kata 'Taban'.

Kata 'gemuk' memunculkan variasi leksikal. Desa Sungsang I menggunakan kata 'gəndot', Desa Sungsang II menggunakan kata 'bontEt', Desa Sungsang III menggunakan kata 'gəmכk', dan Desa Sungsang IV menggunakan kata 'gədi'. Kata 'Hantam' memunculkan variasi leksikal. Kata 'Lanjakela' digunakan di Desa Sungsang I, kata 'slkat' digunakan di Desa Sungsang II, kata 'lajUkela' digunakan di Desa Sungsang III, sedangkan kata 'hajar' digunakan di Desa Sungsang IV.

Kata 'Hitam' memunculkan dua variasi leksikal. Pertama, yaitu 'Iren‘ digunakan di Desa Sungsang I, Desa Sungsang II, Desa Sungsang III, dan Sungsang IV menggunakan kata ' $h \mathrm{lt} \varepsilon \mathrm{Em}$ '. Kata 'ibu' memunculkan dua variasi leksikal. Varian pertama, yaitu 'Emak' digunakan di Desa Sungsang I, Desa Sungsang II, Desa Sungsang III, sedangkan 'Ebo' digunakan di Desa Sungsang IV. Kata 'jatuh' memunculkan tiga variasi leksikal. Varian pertama, yaitu ' jəlepak' digunakan di Desa Sungsang I, varian kedua, yaitu 'campak' digunakan di Desa Sungsang II, Desa Sungsang IV, sedangkan varian ketiga 'ǹampak' digunakan di Desa Sungsang III. Kata 'Kami, kita' memunculkan dua variasi leksikal. Varian pertama, yaitu 'Tobo' digunakan di Desa Sungsang I, Desa Sungsang II, sedangkan varian kedua, yaitu 'Kame' digunakan di Desa Sungsang III, dan Desa Sungsang IV. Kata 'Kakek' memunculkan variasi leksikal. Kata 'yEk' digunakan di Desa Sungsang I, kata 'gəde' digunakan di Desa Sungsang II, kata 'lyEk' digunakan di Desa Sungsang III, kata 'gEdEh' digunakan di Desa Sungsang IV.

Kata 'Kutu' memunculkan dua variasi leksikal. Kata 'tUmU' digunakan di Desa Sungsang I, Desa Sungsang II, kata 'tUme' digunakan di Desa Sungsang III, 
dan Desa Sungsang IV. Kata 'Lihat' memunculkan tiga variasi leksikal. Varian pertama, yaitu 'ǹele' digunakan di Desa Sungsang I, kata 'jinכk' digunakan di Desa Sungsang II, Desa Sungsang III, sedangkan kata 'ǹin0' digunakan di Desa Sungsang IV.

Kata 'Nenek' memunculkan variasi leksikal. Desa Sungsang I menggunakan kata 'ǹebo', Desa Sungsang II menggunakan kata 'bəyวt', Desa Sungsang III menggunakan kata 'ǹEk' Desa Sungsang IV menggunakan kata 'ǹai'. Kemudian, Kata 'Perempuan' memunculkan dua variasi leksikal. Varian pertama, yaitu 'wadつn' digunakan di Desa Sungsang I, Desa Sungsang II, Desa Sungsang III, 'bətIne' digunakan di Desa Sungsang IV. Kata 'Sungai' memunculkan dua variasi leksikal. Varian pertama, 'sUni' digunakan di Desa Sungsang I, Desa Sungsang II, kata 'sUne' digunakan di Desa Sungsang III, dan Desa Sungsang IV. Selanjutnya, kata 'Buruk' memunculkan dua variasi leksika. Di Desa Sungsang I, Desa Sungsang II menggunakan kata 'Tak bagos' sedangkan Desa Sungsang III dan Desa Sungsang IV menggunakan kata 'bכrok'.

c. Persamaan Bahasa Musi di Sungsang

Pada kategori kosakata Swadesh persamaan di Desa Sungsang I, Desa Sungsang II, Desa Sungsang III, dan Desa Sungsang IV terdapat pada nomor ( 1 , $5,6,7,8,11,15,20,23,24,26,27,28,30,31,33,36,37,38,39,40)$ kata 'air' dengan transkripsi fonetik 'aEr', kata 'balik' dengan transkripsi fonetik 'Bale', kata 'besar' dengan transkripsi fonetik 'gədi', kata 'buah' dengan transkripsi fonetik 'bUah', kata 'bunuh' dengan transkripsi fonetik 'bכnวh', kata 'dengan' dengan transkripsi 'dEnEn', kata 'engkau' dengan transkripsi fonetik ' kau', kata 'istri' dengan transkripsi fonetik 'blnl', kata 'kaki' dengan transkripsi fonetik 'sUkU', kata 'kamu' dengan transkripsi fonetik 'kau,' kata 'kening' dengan transkripsi fonetik 'batวk', kata 'kering' dengan transkripsi fonetik 'kəren', kata 'lelaki' dengan transkripsi fonetik 'lanan', kata 'leher' dengan transkripsi fonetik 'Gorokkan', kata 'orang' dengan transkripsi fonetik 'Uran', kata 'tajam' dengan transkripsi fonetik 'landEp', kata 'tarik' dengan transkripsi fonetik ' tarEk', kata 'tidur' dengan transkripsi 'tədつk', kata 'tua' dengan transkripsi ' tUe', kata 'kabut' dengan transkripsi fonetik 'kabət'.

\section{KESIMPULAN DAN SARAN}

Berdasarkan hasil hasil penelitian, dari daftar kosakata dasar Swadesh yang berjumlah 200 kata, dapat diketahui variasi leksikal bahasa Musi di Sungsang yang meliputi Desa Sungsang I, Desa Sungsang II, Desa Sungsang III, dan Desa Sungsang IV. Variasi leksikal bahasa Musi, Desa Sungsang I dengan jumlah variasi 60 kosakata, sedangkan Desa Sungsang II memiliki variasi 53 kosakata, Desa Sungsang III memiliki variasi 47 kosakata, dan Desa Sungsang IV memiliki variasi 52 kosakata. Dibandingkan dengan desa yang lain Desa Sungsang I lebih banyak variasi bahasa Musi karena Desa Sungsang I banyak masyarakat pendatang dan Desa Sungsang I lebih luas pencakupan lorongnya dibandingkan dengan desa lain. Sementara persamaan bahasa Musi di Sungsang banyak terdapat pada Desa Sungsang III dengan jumlah 162 kosakata yang sama dibandingkan dengan Desa Sungsang I, II, dan IV.

Variasi leksikal ini terjadi di masing-masing desa. Pemakaian kosakata yang bervariasi meskipun berada pada satu kawasan, namun memiliki perbedaan dan persaman kosakata bahasa Musi. Selain itu, kemunculan variasi lain dalam suatu wilayah bisa disebabkan karena Sungsang merupakan pintu lalu lintas. 
Faktornya dapat berupa interaksi penutur bahasa dalam satu desa ke desa lainnya. Letak geografis dan banyaknya penduduk luar yang tinggal juga bisa menyebabkan bahasa Musi mengalami perubahaan kosakata dari waktu ke waktu. Harapannya bagi Balai Bahasa Sumatera Selatan dan lembaga terkait untuk bisa mendokumentasikan bahasa Musi sebagai salah satu bahasa daerah yang ada di Indonesia sebagai identitas bangsa.

\section{DAFTAR PUSTAKA}

Aliana, Z. A. (2003). Regional Language: Multiple Topics. Inderalaya: Faculty of Teacher Training and Education.

Aslinda, S. L. (2010). Introduction to Sociolinguistics. Bandung: Refika Aditama.

Chaer, A. \& Agustina, L. (2010). Sociolinguistic Introduction Early. Jakarta: Rineka Cipta.

Dedi, D., \& Cekman, C. (2018). Kohesi Leksikal dalam Acara Berasan Masyarakat Sindang Kelingi Musi Rawas. Silampari Bisa: Jurnal Penelitian Pendidikan Bahasa Indonesia, Daerah, dan Asing, 1(1), 67. doi:10.31540/silamparibisa.v1i1.15

Djajasudarma, F. (1993). Method of Linguistic Advance Research Methods and Study. Bandung: PT Eresco.

Felicia. (2001). Pengertian Bahasa. Jakarta: PT Gramedia Pustaka.

Mahsun. (2006). Language Research Methods. Jakarta: PT Raja Grafindo Persada.

Mutoharoh, M., Sulaeman, A., \& Goziyah, G. (2018). Interferensi Morfologi dalam Karangan Narasi Mahasiswa Thailand Semester IV Pendidikan Bahasa dan Sastra Indonesia FKIP Universitas Muhammadiyah Tangerang. Silampari Bisa: Jurnal Penelitian Pendidikan Bahasa Indonesia, Daerah, dan Asing, 1(1), 87. doi:10.31540/silamparibisa.v1i1.10

Noermanzah \& Friantary, H. (2019). Development of Competency-Based Poetry Learning Materials for Class $X$ High Schools. International Journal of Recent Technology and Engineering, 8(4).

Noermanzah, N. (2017). Struktur Kalimat Tunggal Bahasa Sindang di Kota Lubuklinggau dan Pengaruhnya dalam Pembelajaran Bahasa Indonesia. AKSIS: Jurnal Pendidikan Bahasa Dan Sastra Indonesia, 1(1), 2. doi:10.21009/aksis.010101

Pateda, M. (1988). Linguistics An Introduction. Bandung: Space.

Sudaryanto. (2015). Metode dan Teknik Analisis Bahasa. Yogyakarta: Sanata Darma University Press. 